\title{
JOB DEMANDS AND JOB RESOURCES IN THE MINISTRY
}

Authors:

Chenell Buys ${ }^{1}$

Sebastiaan Rothmann ${ }^{2,3}$

\section{Affiliations:}

${ }^{1}$ Private Consultant,

Nelspruit, South Africa

${ }^{2}$ School of Behavioural

Sciences, North-West

University, South Africa

${ }^{3}$ Department of Human

Science, University of

Namibia, Namibia

Correspondence to:

Sebastiaan Rothmann

e-mail:

ian@ianrothmann.com

Postal address:

PO Box 8060, Swakopmund,

Namibia

Keywords:

demands; resources; ministry; overload; social support

\section{Dates:}

Received: 05 Mar. 2009

Accepted: 30 July 2009

Published: 09 Sept. 2009

How to cite this article:

Buys, C., \& Rothmann, S. (2009). Job demands and job resources in the ministry. SA Journal of Human Resource Management/SA Tydskrif vir Menslikehulpbronbestuur 7(1), Art. \#202, 10 pages. DOI: 10.4102/sajhrm.v7i1.202

\section{This article is available} at: http://www.sajhrm.co.za

(c) 2009. The Authors. Licensee: OpenJournals Publishing. This work is licensed under the Creative Commons Attribution License.

\section{ABSTRACT}

The objective of this study was to investigate ministers' job demands and job resources using a qualitative design $(n=9)$. Fifteen themes emerged from the interviews. A cross-sectional survey design was used to study ministers' experiences of job demands and job resources $(N=115)$. A principal factor analysis with a varimax rotation resulted in eight reliable factors. These factors included as job demands: pace and amount of work and emotional demands; and as job resources: growth opportunities, instrumental support, congregational support, autonomy, social support and job significance.

\section{INTRODUCTION}

The ministry is a unique and demanding profession (Han \& Lee, 2004). The demands that ministers encounter in their work are regarded as more intense than demands experienced by managers in organisations (Kriel, Wilders, Strydom \& Breytenbach, 2005). Demanding aspects of a minister's job are to help, motivate, empower, and inspire their parishioners (Burger, 2004). Preaching is one of the ways in which these functions are fulfilled. Ministers preach because they believe they have a calling to do so, not just because they are paid to do so. Therefore, ministers do not enter into a contract with the congregation, but rather work for the congregation because of their calling (Burger \& Wepener, 2004).

This study focuses on ministers in the Reformed church. In addition to preaching, the minister's role within the Reformed tradition is also centred on teaching and pastoral care (Burger, 2004). In our current secular and pluralistic society, the Christian is not taught anywhere else other than within the institutions of the church. Therefore, the Church and also its ministers are faced with the responsibility of teaching the community about faith. Furthermore, ministers are expected to nurture the physiological and emotional well-being of their parishioners (Blanton \& Morris, 1999). This is not an easy task, because one of the three ways in which a minister can be hurt in his office is through negative stories spread by people he has attempted to reach through pastoral care (Van den Berg, 2004).

Apart from preaching, teaching and pastoral care, ministers also perform the roles of organiser and administrator (Kay, 2000; Kriel et al., 2005). According to Article 16 of the Church Order of the Reformed Church (Psalmboek, 2003), the office of a minister of the Word is to persevere in prayers, proclaim the Word and administer the sacraments, attend to and oversee his fellow ministers, the elders, deacons and Church members, and ultimately, in conjunction with the elders, exercise the discipline of the Church and ensure that everything in the Church takes place in an orderly and proper manner (GKSA, 1862).

Although ministers perform many different roles, they do not have a definite job description. According to Smit (2004), a minister does not need a job description because his calling is from God and not from the congregation. A minister has the autonomy to determine what actions or functions are important (Kriel et al., 2005). This causes some difficulty because there are some responsibilities ministers have that form part of preaching and teaching. There are also responsibilities a minister must perform that are unexpected (e.g. that of pastoral care) (Kriel et al., 2005). Although the office of a minister is determined by God and the minister stands in service to God, it happens that some ministers still do not know what is expected of them in their office (Burger, 2004). Ministers sometimes do work that is not part of their ministry (Smit, 2004). Many parishioners also experience an uncertainty about what the minister's job is exactly and what is expected of him (Burger \& Wepener, 2004; Kriel et al., 2005). Most parishioners do not have an idea what the minister does apart from officiating at normal Sunday service, weddings and funerals (Kriel et al., 2005).

Uncertainty is experienced in ministries worldwide. The vague awareness of the identity of the minister's office is largely because of the disintegration of the Christ Centred Church (Burger \& Wepener, 2004). Recently, churches have become more and more focused on missionary work and therefore expect different things from ministers who originally might have worked within a purely Christian paradigm. Consequently, the office of a minister entails more than preaching and teaching it is also about the missionary leadership of God's people, the Church (Burger \& Wepener, 2004).

Not only is the office of the minister of the Word in South Africa faced with this changing ecclesiastical context (Wepener, 2004), but it also has to face the specific political and social changes in the country. Ministers are now increasingly faced with multicultural congregations. In South Africa, ministers must lead a congregation within a liberal democracy wherein freedom and equality are the order of the day in all spheres of life. To complicate things further, ministers need to work together ecumenically with leaders of other denominations, which demands a different focus from the traditional 'only we have the whole truth' (Van der Merwe, 1996). Some congregations also require a minister to use another language besides his own (Burger \& Wepener, 2004). Furthermore, research has shown that different generations have unique expectations, which often turn into demands for a minister. Some of these generations have their own forms of spirituality that have to be liturgically accommodated by the minister (Burger \& Wepener, 2004). 
Secularisation also has an influence on the Church. The Church has to survive in a community that does not support the life and ethos of the Church (e.g. shops that are open on a Sunday, while the Church is struggling to maintain services). Secularisation leads to a reduction in the influence of the Church on the community, and has in turn, influenced the life of the Church. Almost every Protestant Church has eagerly adopted the personnel policies of business (Burger \& Wepener, 2004). Further contextual challenges to a minister's work are the high crime rate, poverty and HIV/AIDS (Van der Merwe, 1996). Within this context, a minister must lead parishioners to fulfil their calling in life (Burger \& Wepener, 2004).

Currently, influences from the world set an increasing number of demands on a minister. A minister, like any other Christian, is subject to normal stressors, especially stress factors linked to the caring profession. Specific stressors that a minister experiences include: the discrepancy between his initial ideal of the ministry and the harsh realities that he has to handle and process; his struggle to live his calling while his workload is extremely high; his struggle to balance the roles of servant and leader and the consequent confusion and experience of being overburdened as it is sometimes expected from him to be everything to everyone (Grobbelaar, 2007). The above factors can cause a minister to experience compassion exhaustion because of his involvement with other stressed and suffering people (Coetzer, 2004).

Parishioners tend to have high expectations of the minister's personal and professional competence, and these expectations are often experienced by ministers as unrealistic and intrusive (Morris \& Blanton, 1994; Van den Berg, 2004). Ministers also work long hours, often for low pay compared with similarly qualified individuals in other occupations. A recent study by Morris and Blanton (1994) regards financial issues as the category of stressor thought to be of greatest concern by denominational officials (see also Lee, 1999). Later in a minister's career, the most commonly reported source of stress is his/her relationship with the congregation, particularly in the realm of personal and ideological conflicts (Lee, 1999).

The indistinct parameters of a minister's job can lead to calling loss and large-scale professional unhappiness (Burger, 2004). A recent study demonstrates that interactions of a critical and demanding nature in the Church have a detrimental impact on subjective well-being, and that this has a greater adverse effect on the minister than on rank-and-file members of the congregation (Krause, Ellison \& Wulff, 1998). However, the ministry also has personal benefits. A large mail and telephone survey of ministers revealed that four out of five respondents were at least somewhat satisfied in the ministry (Lee, 1999). Significant majorities also reported that serving in their congregation had increased their passion for the ministry, and that their ministry efforts had been very much worthwhile (Lee, 1999).

A study on Reformed Church ministers in South Africa showed that ministers indeed experience distress in their work (Grobbelaar, 2007). Some of the stressors can be linked to their specific job characteristics. The most prominent studied job characteristics included: skill variety, autonomy and job demands (Kompier, 2003). The Job Demand-Resources (JD-R) model makes it possible to classify the types of demands and resources that ministers face. The general assumption of the JD-R model is that whereas every occupation may have its own specific risk factors, these factors can be classified into two general categories, namely job demands and job resources (Demerouti, Bakker, Nachreiner \& Schaufeli, 2001).

During the past three decades, many studies have shown that job characteristics can have a profound impact on employee wellbeing (Bakker, Demerouti \& Schaufeli, 2003; Bakker, Demerouti, Taris, Schaufeli \& Schreurs, 2003; De Jonge et al., 2001; De Jonge \& Schaufeli, 1998; Schaufeli \& Bakker, 2004). For example, research has revealed that job demands (such as high work pressure and emotional demands) may lead to exhaustion and impaired health. Although job demands are not necessarily negative, they may turn into job stressors when meeting those demands requires high effort. Job resources (such as social support and autonomy) may instigate a motivational process leading to jobrelated learning, work engagement and commitment. Hence, job resources are not only needed in order for a minister to deal with job demands and to 'get things done', but important in their own right (Schaufeli \& Bakker, 2004).

Therefore, job demands and job resources have an impact on individual well-being. However, little is known about how ministers experience the demands and resources in their occupation. The aim of this study was to investigate the job demands and job resources that ministers in the Reformed Church in South Africa experience.

\section{The Job Demands-Resources (JD-R) Model}

The JD-R model acknowledges that parsimony is an important feature of every research model but assumes at the same time that individuals in different occupations may encounter various kinds of job demands and job resources (Demerouti et al., 2001). 'Job demands' refer to those physical, social, or psychological (cognitive and emotional) efforts or skills which are associated with certain physiological or psychological costs. Examples are high work pressure, an unfavourable physical environment and emotionally demanding interactions with clients (Janssen, Peeters, De Jong, Houkes \& Tummers, 2004). 'Job resources' refer to those physical, psychological, social, or organisational aspects of the job that are functional in achieving work goals; reducing job demands and the associated physiological and psychological costs; or stimulating personal growth, learning and development (Janssen et al., 2004).

TheJD-Rmodelisbased on twodifferentunderlying psychological processes. The first argues that a health impairment process, poorly designed job or chronic job demands (e.g. overload, emotional demands) exhaust employees' mental and physical resources and may therefore lead to the depletion of energy (i.e. a state of exhaustion) and health problems (Bakker \& Demerouti, 2006). The second process is motivational in nature, whereby it assumes that job resources have motivational potential and lead to high work engagement, low cynicism and excellent performance. Job resources may thus foster an individual's growth, learning and development (intrinsic motivation) or satisfy an individual's needs for autonomy, competence and relatedness (extrinsic motivation) (Bakker \& Demerouti, 2006).

Ministers, as care-givers, are exposed to demanding work situations, including overload, long work hours, role conflict, and client-related demands such as contact with help seekers with problems as well as chronically ill, terminal or dying clients (Redelinghuys \& Rothmann, 2005). Additional demands that ministers are faced with include time constraints and the gap between illogical expectations and the reality of daily routine (Tomic, Tomic \& Evers, 2004). According to Roux (1992), ministers experience the following demands in the ministry: workload, role instructions and role expectations, work circumstances, academic inadequacy, co-ministers and languishing member numbers. Scholtz (1996) found that the job demands of ministers include work pressure, disagreement in the congregation, the finances of the congregation, the relationship with a co-minister, unfair critique and resistance, political situations, adapting in the congregation and uncommitted parishioners. Ministers find themselves in a unique position. Not only do they experience demands and expectations from their Church council and congregation but they perceive their occupation as a Godly calling (Redelinghuys \& Rothmann, 2005).

The job resources of ministers may be located at the level of the congregation at large (e.g. pay, job security); interpersonal and social relations (e.g. co-minister support, Church council 
relationship); the organisation of work (e.g. role clarity, participation in decision making); or at the level of the task (e.g. skill variety, task identity, task significance, autonomy, or performance feedback) (Janssen et al., 2004). The latter job resources are the core dimensions included in Hackman and Oldham's (1976) well-known Job Characteristics model. In this model they argue and show that these job characteristics have motivational potential because they make employees' work meaningful, hold them responsible for work processes and outcomes and provide them with information about the actual results of the work activities (Hackman \& Oldham, 1980). Demerouti et al. (2001) showed that job resources (such as job autonomy and feedback) are particularly related to job satisfaction, job challenge and job involvement (to be considered as motivational constructs), whereas job demands are primarily related to emotional exhaustion and psychosomatic health complaints (i.e. adverse health outcomes). Rothmann, Mostert and Strydom (2006) found that job demands include overload whereas job resources include growth opportunities, organisational support, advancement and job security. These factors correspond with the two factors found by Demerouti et al. (2001) and Schaufeli and Bakker (2004). Therefore, it seems that the factorial structure of job demands and job resources is valid.

The Vitamin model (Warr, 1994) regards job characteristics as vitamins that can have a specific effect on individuals. This model holds that mental health is affected by environmental psychological features such as job characteristics in a way that is analogous to the non-linear effects that vitamins are supposed to have on individuals' physical health. Generally, vitamin intake initially improves health and physical functioning, but beyond a particular level of intake no further improvement is observed. Continued intake of vitamins may lead to two different kinds of effects. First, a so-called constant effect might occur. According to Warr (1994), vitamins C and E have such a constant effect on the human body (health neither improves nor are noxious consequences observed that impair the individual's physical health). Therefore, the label 'Constant Effect' (CE) is used to denote this particular relationship (De Jonge \& Schaufeli, 1998).

Secondly, an overdose of vitamins leads to a toxic concentration in the human body ('hypervitaminosis'), which causes poor bodily functioning and ill health. Among others, vitamins A and $\mathrm{D}$ are known to be toxic when taken in large quantities. For this reason Warr (1994) has used the label 'Additional Decrement' (AD) to denote the inverted U-shaped curvilinear relationship. Warr (1994) argues that the effects of job characteristics upon mental health parallel the ways in which vitamins act upon the human body (De Jonge \& Schaufeli, 1998). For example, very high levels of job autonomy are potentially harmful since they imply uncertainty, difficulty in decision-making and high levels of responsibility in the job. Following this line of reasoning, we could refer to Warr's vitamins as 'work vitamins' (De Jonge \& Schaufeli, 1998).

The six job characteristics that Warr (1994) assumes have the effects similar to vitamins A and D include:

- Opportunity for personal control (job autonomy): latitude in decision-making and the influence of the employees to choose their own objectives, to schedule their tasks and their rules of performance and to predict the consequences of actions

- Externally generated goals (job demands): the degree to which the environment makes demands upon the employee

- Opportunity for interpersonal contact (social support): loneliness versus friendship, social support and opportunities to compare one's opinions and abilities with those of other people

- Opportunity for skill use (skill utilisation): the degree to which the utilisation and development of skills is required by the job
- Variety (skills variety): the occurrence of repetitive and invariant routine actions in diverse and novel situations

- Environmental clarity (task feedback): the availability of feedback information about the result of one's actions, certainty and clarity of role expectations and requirements.

These vitamins therefore have a positive effect on health up to a certain point. But after this point they have a damaging effect on health.

The remaining three job characteristics are supposed to follow the CE pattern, in which these vitamins show a positive effect on health up to a certain level, but not beyond it. These include:

- Availability of money (salary): low or high income

- Physical security (safety): protection against physical threat, security of tenure and job safety in the work market

- Valued social position (task significance): esteem from other people within social networks, occupational prestige.

There is empirical support for the Vitamin model (De Jonge \& Schaufeli, 1998; Le Blanc, Bakker, Peeters, Van Heesch \& Schaufeli, 2001). Warr (1994) also indicates that these nine job characteristics do act as predicted in isolation (Kompier, 2003).

Therefore, the Vitamin model consists of nine features of jobs that act as potential determinants of job-related mental health. Not surprisingly, these characteristics include, among others, those that are featured in the Job Characteristics model (Hackman \& Oldham, 1980) and the Demand-Control-Support model (Rodrìguez, Bravo \& Peiró, 2001; Van Derdoef \& Maes, 1999). According to the JD-R model, every occupation may have its own specific risk factors associated with job stress, but regardless of the occupation, these factors can be classified in two general categories; job demands and job resources (Bakker \& Demerouti, 2006). In this study the JD-R model is used to classify the job characteristics identified by the Vitamin model and uses this information to develop a questionnaire to measure job demands and job resources as experienced by ministers.

\section{RESEARCH DESIGN}

\section{Research approach}

In order to reach the objectives, this study was done in two phases. The first phase consisted of a qualitative design from a phenomenological approach. Because there were no studies done on the job demands and job resources as perceived by Reformed Church ministers in South Africa, the objective of this research design was to determine these possible job demands and job resources. In the second phase, a cross-sectional design was used with a survey as the data collection technique. The objective of this design was to develop a questionnaire which can be used to study the job demands and job resources experienced by ministers. Cross-sectional designs are appropriate where groups of participants at various stages of development are studied simultaneously, whereas the survey technique of data collection gathers information from the target population by means of questionnaires (Burns \& Grove, 1993).

\section{Research method Participants}

The study population could be defined as a non-probability purposive voluntary sample of Reformed Church ministers in South Africa. For the first phase a sample of ministers $(N=9)$ was interviewed. Data reached saturation (Woods \& Catanzaro, 1988) after the eighth interview. One more interview was conducted to ensure saturation of the data. In the second phase of the study the total population of 232 ministers currently in the ministry was targeted. However, six of the ministers did not have an email or a postal address and therefore a total of 226 Internet questionnaires were sent out. Questionnaires were completed anonymously on the Internet, but were identifiable by means of usernames and passwords. This allowed follow-up emails and phone calls to be directed to ministers who failed 
TABLE 1

Characteristics of the participants

\begin{tabular}{|c|c|c|c|}
\hline ITEM & CATEGORY & FREQUENCY & PERCENTAGE (\%) \\
\hline \multirow[t]{7}{*}{$\overline{\text { Age }}$} & $18-25$ years & 2 & 1.7 \\
\hline & $26-30$ years & 7 & 6 \\
\hline & $31-35$ years & 8 & 7 \\
\hline & $36-40$ years & 10 & \\
\hline & $41-45$ years & 18 & 15 \\
\hline & $46-50$ years & 24 & 20 \\
\hline & $51+$ years & 46 & 40 \\
\hline \multirow[t]{4}{*}{ Qualification } & ThB & 39 & 33 \\
\hline & Honours & 15 & 13 \\
\hline & Master's & 31 & \\
\hline & $\mathrm{PhD}$ & 30 & \\
\hline \multirow[t]{4}{*}{ Marital status } & Single & 9 & \\
\hline & Married & 106 & \\
\hline & Separated & 1 & \\
\hline & Remarried & 5 & \\
\hline \multirow[t]{8}{*}{ Ministry experience } & $0-5$ years & 17 & 14 \\
\hline & $6-10$ years & 11 & \\
\hline & $11-15$ years & 12 & \\
\hline & $16-20$ years & 23 & \\
\hline & $21-25$ years & 20 & \\
\hline & $26-30$ years & 13 & \\
\hline & $31-35$ years & 14 & \\
\hline & $36+$ years & 5 & \\
\hline \multirow{5}{*}{$\begin{array}{l}\text { Ministry experience in } \\
\text { current congregation }\end{array}$} & $0-5$ years & 59 & \\
\hline & $6-10$ years & 30 & \\
\hline & $11-15$ years & 3 & \\
\hline & $16-20$ years & 11 & \\
\hline & $21-30$ years & 12 & 10 \\
\hline \multirow[t]{7}{*}{ Congregation size } & $0-150$ & 11 & \\
\hline & $151-300$ & 37 & \\
\hline & $301-600$ & 38 & 33 \\
\hline & $601-900$ & 11 & \\
\hline & $901-1200$ & 7 & \\
\hline & $1201-1500$ & 6 & \\
\hline & $1501+$ & 5 & \\
\hline \multirow{3}{*}{$\begin{array}{l}\text { Ministers in current } \\
\text { congregation }\end{array}$} & One minister & 84 & \\
\hline & Two ministers & 17 & \\
\hline & $\begin{array}{l}\text { Three or more } \\
\text { ministers }\end{array}$ & 14 & \\
\hline
\end{tabular}

Note: ThB: The theological degree obtained after 6 years of study

to respond. Ten of the ministers were not able to complete the questionnaire due to their workload, while other ministers asked to be excused from the research because of medical reasons. A total of 115 completed the questionnaire, establishing a response rate of $50.88 \%$. Descriptive information of the sample is given in Table 1 .

As can be seen in Table 1, the participants were all male (100\%). This is because female ministers are not allowed in the Reformed religion. Most participants were over the age of $46(60.9 \%)$. Regarding marital status, $92.2 \%$ of the participants were married, and most of the participants had three children $(40 \%)$. Nearly half of the participants (37.4\%) had been in the ministry for 16 to 25 years. It is interesting to note that $39(33.9 \%)$ of the participants were qualified with a theological degree while $61(53.1 \%)$ of the participants had a master's or doctoral degree. Only $26(22.6 \%)$ of the ministers had been in their current congregations for 11 to 30 years while $59(51.9 \%)$ and $30(26.1 \%)$ had been in their current congregations for 0 to 5 and 6 to 10 years respectively. Most congregations were between the sizes of 301 to 600 (33.0\%) and 151 to $300(32.2 \%)$. Of the 115 participants, $84(73 \%)$ were the only minister in their congregation.

\section{Measuring battery}

A structured interview based on the phenomenological paradigm was used in the first phase of this research. The researcher studied the phenomenon without predetermined expectations of categories and tried to understand the data from the perspective of the participant. The definition of job demands and job resources was given and the participants were asked the following two questions: 'Mention all the physical, social and ministry aspects in your work that require of you any physical or psychological effort or skill'; 'Mention all the resources in your ministry that enable you to do your work to the best of your ability'. Themes from these interviews were used to compile a questionnaire to measure the job demands and job resources of ministers.

The Job Demands-Resources Questionnaire (JD-RQ) consisted of 10 job characteristics which can be classified as either job demands or job resources. The job demands included pace and amount of work (seven items, e.g. 'Do you have an excessive amount of work to do?') and emotional demands (three items, e.g. 'Are you confronted in your work with things that affect you personally?'). While the job resources included: skill variety (three items, e.g. 'Do you feel that you have enough variety in your work right now?'); skill utilisation (six items, e.g. 'Does your job require that you learn new things?'); task significance (nine items, e.g. 'Does your job have a significant effect on the lives or well-being of other people?'); job autonomy (seven items, e.g. 'Does the Church council permit you to decide for yourself how to go about your work?'); task feedback (three items, e.g. 'Does your work itself provide clues about how well you are doing in your job aside from any feedback from your co-workers?'), salary (seven items, e.g. 'Does your congregation pay you fairly for what you contribute?'), safety (four items, e.g. 'Do you experience job insecurity?') and support from friends, family, co-workers and the congregation (15 items, e.g. 'Do you have friends you can rely on?'). Each subscale was measured on a five-point Likert scale ranging, from 1 (not at all) to 5 (a great deal).

A questionnaire was developed to gather information regarding the demographical characteristics of the participants. This questionnaire included gender, age, educational qualification, marital status, number and age of children, years working in the ministry, years working in the current congregation, current congregation size, income and whether or not there was a second minister at their current congregation.

\section{Research procedure}

The Internet has been shown to be a valid source of data collection (Bakker et al., 2003a). A letter concerning information regarding the study with instructions and a link to the questionnaire was sent to all targeted ministers of the Reformed church. The webbased questionnaire comprised 158 questions which measured job demands, job resources, burnout, engagement, and coping by ministers. A total of 64 items were used to measure job demands and job resources. The ministers were asked to complete the questionnaire on the web. The responses of the participants were automatically sent to the researcher. After a month, the researcher again sent a notice about the study to all ministers. The ministers had a total of three months in which to complete the questionnaire.

\section{Data analysis}

To analyse the qualitative data, the results of the interviews were transcribed verbatim and then coded by the researcher by means of content analysis. Content analysis consists of various steps (Giorgi, 1985; Kerlinger, 1986). First, the context (for example the entire set of verbal answers of the participants) universalised in order to be able to define and categorise it. Second, the sub-units, namely words and themes of the analysis, were determined. The researcher read the response notes in order to form an overall picture. Afterwards, the researcher read them once again in order to determine the themes. A sub-theme is usually a sentence and is more difficult but also more useful to analyse. Sub-themes were combined in order to determine the themes. The analysis of the information was continued until recurring themes were identified. Third, unnecessary information was removed from the data and the meaning of the rest of the subunits was determined by linking them to the whole picture. Last, the concrete language of the participants was converted into scientific language and concepts. The precise words of the 
participants were used in support. Objects per category were counted and placed in order of preference. The trustworthiness of the content analysis was promoted by the coding that was done by the researcher and a co-coder. A literature control was done to investigate relevant research in order to determine the comparativeness and uniqueness of the current research (Krefting, 1991).

The statistical analysis was carried out with the help of the SPSS program (SPSS, 2003). Descriptive statistics (e.g. means and standard deviations) were used to analyse the data. Exploratory factor analyses and Cronbach alpha coefficients were used to assess the validity and reliability of the constructs that were measured in this study. Coefficient alpha contains important information regarding the proportion of variance of the items of a scale in terms of the total variance explained by the particular scale (Clark \& Watson, 1995). Correlations were then performed to determine which factors correlated with one another.

\section{RESULTS}

\section{Qualitative results}

The results obtained from the interviews are shown in Table 2. Fifteen main themes were identified in the interviews. Eight of the main themes represent the job demands that ministers experienced whereas seven represent the job resources. The themes were classified as representing job demands or resources based on the definition of these concepts by Demerouti et al. (2001). Table 2 shows the themes with the total number of ministers supporting each theme.

The eight main themes regarding job demands as obtained from the study made it clear that ministers experienced preaching, teaching, management and organisation, service to community, service to the Reformed denomination, social activities, pastoral care and personal demands as demands in the ministry.

- Preaching: Five ministers indicated that they considered sermon preparation a demanding aspect of their work. Furthermore, all the participants found the sermons on Sundays to be demanding.

- Teaching: It is clear that participants regarded catechism, Bible studies and small-group meetings and and equipping the Church council as demanding aspects of their teaching environment. Catechism was mentioned by eight

TABLE 2

The experience of job demands and job resources of ministers

\begin{tabular}{lll}
\hline THEMES & & $\begin{array}{c}\text { TOTAL } \\
\boldsymbol{N}=\mathbf{9}\end{array}$ \\
\hline Job Demands and Job Resources & \\
Theme 1 & Preaching & 9.0 \\
Theme 2 & Teaching & 6.3 \\
Theme 3 & Management and organisation & 6.0 \\
Theme 4 & Service to community & 3.0 \\
Theme 5 & Service to Reformed denomination & 7.0 \\
Theme 6 & Social activities & 2.8 \\
Theme 7 & Pastoral care & 7.0 \\
Theme 8 & Personal demands & 3.0 \\
Theme 9 & Support from outside the congregation & 4.7 \\
Theme 10 & Support from Church structures & 1.0 \\
Theme 11 & Support sources from the congregation & 3.2 \\
Theme 12 & Administrative support & 7.0 \\
Theme 13 & Spiritual resources & 4.0 \\
Theme 14 & Supporting mechanisms & 8.0 \\
Theme 15 & Growth opportunities & 4.0 \\
\hline
\end{tabular}

participants, seven participants mentioned Bible studies and small groups while only four participants mentioned equipping the Church council.

- Management and organisation: Ministers indicated that meetings and administration were both demanding aspects in the ministry. Participants indicated that they experienced meetings as demanding more often than administration. Not only does a minister provide a service to the congregation but he also has to deliver an administrative and leadership role in the church.

- Service to the community: Five participants indicated that service to the community, such as missionary service, was demanding. One participant said that being the head of a home for the elderly, serving on the executive committee of a school and delivering sermons at old-age homes were demanding aspects. One participant indicated that officiating at the opening of schools was also demanding.

- Service to the Reformed denomination: Apart from the service a minister delivers to the congregation, ministers also seem to deliver a service to the Reformed denomination. Seven ministers indicated that they were also bound by some obligations to the Reformed Church as a whole.

- Social activities: Five ministers indicated that they had demands like youth activities, while two mentioned family or area activities and one mentioned activities involving the elderly. Three participants indicated that they considered the camps they had to organise for their congregation a demanding aspect.

- Pastoral care: In this study all the ministers indicated that house visits and pastoral counselling were demanding in the ministry, while only three ministers indicated visits to the elderly as an additional demand.

- Personal demands: Ministers also mentioned that they found the motivational aspect of their work demanding as well as their having to be role models or examples as leaders of their congregations.

Concerning job resources, ministers appear to consider support from outside the congregation, support from Church structures, support from the congregation, administrative support, spiritual resources, supporting mechanisms and growth opportunities as important job resources.

- Support from outside the congregation: Four of the ministers in this study indicated that they had the support of their family, but only one indicated that he had support from friends. All the participants indicated that the support of coworkers was a resource.

- Support from Church structures: Only one indicated that the enjoyed the support of the Church structures was a resource.

- Support from the congregation: Almost all of the participants indicated that they had support from their Church council, four indicated support from committees while only two indicated support from groups and support from parishioners in their congregation. Only one participant mentioned support from personnel like the Church warden, organist and the secretary of the Church council.

- Administrative support: Almost all the participants indicated that they enjoyed administrative support. One participant said that during the day, his Church office was a great support because it handled all administrative duties and organised all his appointments.

- Spiritual resources: Four participants indicated that they could call on spiritual resources. They mentioned that they regarded their work as a calling and their grace and strength were gifts from God.

- Supporting mechanisms: Equipment like computers, the Internet, phones, photocopying facilities and books were all indicated as resources ministers needed to do their work. Three participants indicated that their own car was a resource to them. Two participants mentioned their house while three participants mentioned their own offices. Three of the participants indicated that money was an important resource. 
TABLE 3

Principal factor analysis with a varimax rotation on the JD-RQ

\begin{tabular}{|c|c|c|c|c|c|c|c|c|c|c|}
\hline ITEM & & $\mathrm{a}_{1}$ & 2 & 3 & 4 & 5 & 6 & 7 & 8 & $h^{2}$ \\
\hline B31 & Do you have to work under time pressure? & 0.75 & -0.00 & -0.13 & 0.00 & -0.05 & 0.04 & 0.02 & 0.03 & 0.58 \\
\hline B26 & Do you have an excessive amount of work to do? & 0.70 & -0.03 & -0.10 & 0.13 & -0.09 & -0.13 & 0.16 & 0.02 & 0.57 \\
\hline B27 & Do you have to work very hard to manage all your demands? & 0.68 & 0.08 & -0.18 & 0.08 & -0.05 & -0.09 & 0.03 & -0.04 & 0.52 \\
\hline B28 & Are your tasks often interrupted before they can be completed? & 0.64 & 0.00 & -0.05 & -0.07 & -0.07 & -0.04 & -0.22 & 0.19 & 0.51 \\
\hline B29 & Does it feel that you always have work left to do at the end of the day? & 0.64 & -0.08 & -0.05 & -0.15 & -0.01 & -0.02 & 0.02 & 0.19 & 0.48 \\
\hline B30 & $\begin{array}{l}\text { Do you feel that you do not have enough time to do your job as well as you would } \\
\text { like to? }\end{array}$ & 0.61 & -0.17 & -0.03 & -0.07 & -0.01 & -0.00 & -0.06 & 0.03 & 0.41 \\
\hline B32 & Do you feel that there are conflicting demands that others make of you? & 0.48 & -0.29 & -0.03 & -0.32 & -0.21 & -0.06 & 0.10 & 0.28 & 0.55 \\
\hline B15 & Do you feel a sense of accomplishment from doing your job? & -0.07 & 0.72 & 0.04 & 0.09 & 0.10 & 0.06 & -0.00 & -0.01 & 0.54 \\
\hline B6 & Does your job enable you to develop your own special ability? & -0.21 & 0.57 & 0.13 & 0.11 & 0.27 & 0.13 & 0.10 & 0.02 & 0.49 \\
\hline B7 & Does your job enable you to grow spiritually? & -0.20 & 0.56 & 0.09 & 0.10 & 0.25 & 0.16 & 0.12 & -0.08 & 0.48 \\
\hline B3 & Do you feel that you have enough variety in your work right now? & -0.05 & 0.55 & 0.14 & 0.15 & 0.18 & 0.19 & 0.16 & 0.09 & 0.45 \\
\hline B49 & Do you feel that you are moving forward in your job? & -0.12 & 0.54 & 0.23 & 0.26 & 0.22 & 0.10 & 0.15 & -0.21 & 0.55 \\
\hline B4 & Does your job require that you learn new things? & 0.03 & 0.51 & 0.11 & 0.24 & -0.14 & 0.09 & 0.36 & 0.20 & 0.53 \\
\hline B37 & $\begin{array}{l}\text { Does your work provide you with many chances to figure out how well you are } \\
\text { doing? }\end{array}$ & -0.01 & 0.50 & -0.13 & 0.44 & 0.02 & 0.09 & -0.14 & -0.11 & 0.50 \\
\hline B14 & Does your job allow you to do something good for other people? & 0.05 & 0.47 & 0.14 & 0.02 & 0.02 & 0.12 & 0.19 & 0.02 & 0.29 \\
\hline B13 & Do you feel that you will achieve something in your current job? & -0.17 & 0.45 & 0.24 & 0.19 & 0.10 & 0.08 & 0.36 & -0.17 & 0.47 \\
\hline B42 & Do you feel that you get paid enough for your work? & -0.24 & 0.11 & 0.81 & 0.06 & 0.09 & 0.02 & -0.03 & 0.13 & 0.74 \\
\hline B40 & $\begin{array}{l}\text { Are your salary and benefits comparable with that of colleagues in the same line of } \\
\text { work? }\end{array}$ & 0.03 & 0.16 & 0.77 & -0.04 & 0.15 & 0.02 & -0.00 & -0.15 & 0.67 \\
\hline B39 & Does your congregation pay you fairly for what you contribute? & -0.13 & 0.07 & 0.74 & 0.12 & 0.23 & 0.08 & -0.02 & 0.06 & 0.65 \\
\hline B41 & Does your job offer you the possibility to progress financially? & -0.15 & 0.15 & 0.67 & 0.08 & -0.08 & 0.08 & -0.13 & 0.01 & 0.52 \\
\hline B56 & Do you receive enough support and guidance from your co-workers? & -0.10 & 0.30 & 0.49 & 0.38 & 0.11 & 0.34 & 0.05 & -0.10 & 0.62 \\
\hline B45 & Do you receive sufficient administrative support to complete your tasks? & 0.12 & -0.01 & 0.48 & 0.14 & -0.02 & 0.21 & 0.27 & -0.20 & 0.42 \\
\hline B57 & $\begin{array}{l}\text { Do you have a network of co-workers with whom you can discuss work-related } \\
\text { problems? }\end{array}$ & -0.01 & 0.33 & 0.48 & 0.21 & 0.09 & 0.27 & 0.04 & -0.09 & 0.47 \\
\hline B38 & $\begin{array}{l}\text { Do your congregation and Church council let you know how well you are performing } \\
\text { your job? }\end{array}$ & 0.04 & 0.19 & 0.10 & 0.66 & -0.02 & 0.06 & 0.06 & -0.14 & 0.51 \\
\hline B61 & $\begin{array}{l}\text { Do you usually receive help from people inside the congregation when something } \\
\text { needs to be done quickly? }\end{array}$ & -0.25 & -0.00 & 0.32 & 0.59 & 0.06 & 0.04 & 0.07 & -0.23 & 0.57 \\
\hline B62 & Does the Church council encourage you in the work that you do? & -0.18 & 0.20 & 0.22 & 0.56 & 0.25 & 0.29 & 0.11 & -0.02 & 0.59 \\
\hline B59 & Can you ask the Church council for advice when you encounter problems at work? & -0.07 & 0.19 & 0.11 & 0.53 & 0.41 & 0.28 & 0.20 & -0.09 & 0.62 \\
\hline B17 & $\begin{array}{l}\text { Do you receive a great degree of respect and fair treatment from the members of } \\
\text { your congregation? }\end{array}$ & -0.06 & 0.06 & 0.17 & 0.50 & 0.43 & 0.15 & 0.18 & 0.02 & 0.52 \\
\hline B18 & Do the people you work with take a personal interest in you? & -0.01 & 0.16 & 0.13 & 0.49 & 0.13 & 0.26 & 0.20 & 0.04 & 0.42 \\
\hline B36 & $\begin{array}{l}\text { Does your actual work itself provide clues about how well you are doing in your job - } \\
\text { aside from any feedback from your co-workers? }\end{array}$ & 0.10 & 0.36 & 0.00 & 0.41 & -0.05 & -0.02 & -0.16 & 0.13 & 0.35 \\
\hline B8 & Does your Church council allow you to attend training courses or to study further? & -0.05 & 0.21 & 0.12 & 0.36 & 0.25 & 0.28 & 0.14 & 0.07 & 0.35 \\
\hline B25 & $\begin{array}{l}\text { Do you feel that your ideas or suggestions about your congregation are not taken } \\
\text { into account? }\end{array}$ & -0.06 & -0.16 & -0.12 & -0.09 & -0.65 & -0.08 & 0.01 & 0.28 & 0.55 \\
\hline B22 & In your job, do you have very little freedom to decide how you do your work? & 0.17 & -0.14 & -0.19 & -0.01 & -0.54 & 0.10 & -0.03 & -0.05 & 0.39 \\
\hline B24 & Do you feel that you are not involved in decisions affecting your job? & -0.09 & 0.00 & 0.02 & -0.24 & -0.46 & -0.14 & 0.06 & 0.11 & 0.32 \\
\hline B21 & Do you have a lot of say about what happens in your work? & -0.07 & 0.23 & 0.15 & 0.25 & 0.45 & -0.13 & 0.30 & 0.08 & 0.46 \\
\hline B19 & Does the Church council permit you to decide how to go about doing your work? & -0.20 & 0.10 & -0.09 & 0.37 & 0.44 & 0.07 & 0.30 & 0.07 & 0.48 \\
\hline B23 & Do you feel that you have little control over many aspects of your job? & 0.24 & -0.19 & -0.06 & -0.08 & -0.30 & -0.08 & 0.08 & 0.03 & 0.21 \\
\hline B52 & Do you receive support from your friends when things get difficult at work? & -0.00 & 0.24 & 0.09 & 0.22 & 0.06 & 0.87 & 0.02 & 0.02 & 0.87 \\
\hline B51 & Can you count on your friends when you encounter difficulties in your work? & -0.01 & 0.35 & 0.18 & 0.18 & 0.10 & 0.75 & 0.08 & -0.09 & 0.78 \\
\hline B50 & Do you have friends on whom you can rely? & -0.08 & 0.26 & 0.15 & 0.17 & 0.16 & 0.65 & 0.10 & -0.05 & 0.59 \\
\hline B58 & Are your relations with colleagues poor? & 0.14 & 0.02 & -0.19 & -0.04 & -0.23 & -0.30 & 0.07 & -0.03 & 0.21 \\
\hline B11 & Can a lot of other people be affected by how well you do your work? & 0.07 & 0.23 & -0.19 & 0.02 & -0.01 & 0.13 & 0.60 & -0.09 & 0.47 \\
\hline B10 & Does your job have a significant effect on the lives or well-being of other people? & 0.08 & 0.05 & -0.01 & 0.21 & 0.01 & -0.00 & 0.53 & 0.16 & 0.36 \\
\hline B12 & Is your job itself very significant or important to you? & -0.03 & 0.34 & 0.13 & 0.00 & 0.09 & 0.14 & 0.44 & 0.06 & 0.36 \\
\hline B5 & Does your job require a high level of skill? & 0.22 & 0.19 & -0.07 & 0.29 & 0.17 & -0.13 & 0.42 & 0.24 & 0.46 \\
\hline B35 & Does your work put you in emotionally upsetting situations? & 0.41 & -0.06 & -0.17 & -0.22 & -0.15 & 0.02 & 0.07 & 0.50 & 0.53 \\
\hline B64 & Does your Church council expect you to be able to do everything on your own? & 0.12 & -0.14 & -0.45 & -0.35 & -0.20 & -0.20 & -0.25 & 0.47 & 0.71 \\
\hline B33 & Are you confronted in your work with things that affect you personally? & 0.33 & -0.01 & -0.20 & 0.02 & -0.08 & 0.07 & 0.15 & 0.41 & 0.35 \\
\hline B34 & Do you have contact with difficult people in your work? & 0.34 & -0.01 & -0.22 & -0.25 & -0.18 & -0.09 & 0.19 & 0.40 & 0.47 \\
\hline B63 & Does your Church look up to you to do everything? & 0.14 & -0.12 & -0.45 & -0.23 & -0.03 & -0.18 & -0.16 & 0.38 & 0.49 \\
\hline
\end{tabular}

${ }^{a}$ Factor labels: 1 - Pace and Amount of Work, 2 - Growth Opportunity, 3 - Instrumental Support, 4 - Congregational Support, 5 - Autonomy, 6 - Social Support, 7 - Job Significance, 8 - Emotional Demands 
- Growth opportunities: Four of the participants indicated that they had been afforded opportunities through which they could grow.

\section{Quantitative results}

A simple principal component analysis was carried out with the 64 items of the JD-RQ. An analysis of the eigen values (> 1.00) indicated that 19 factors explained $74.9 \%$ of the variance. The scree plot indicated that eight factors which explained $51.75 \%$ of the variance could be extracted. A principle factor analysis with a varimax rotation was then performed. The results of the principal factor analysis with loadings of variables on factors and communalities are shown in Table 3. Items with factor loadings higher than 0.30 were retained in the final factor structure (Clark \& Watson, 1995). Labels are suggested for each factor in a footnote.

Table 3 shows that the principal factor analysis with a varimax rotation resulted in eight factors. Items loading on the first factor related to Pace and amount of work and refer to the amount of work that needs to be done in a specific time limit. The second factor represented Growth opportunities and refers to the variety in work, opportunities to learn and career accomplishments. The third factor addressed Instrumental support and refers to financial, administrative and co-worker support. Items on the fourth factor related to Congregational support and refer to the support from the congregation and Church council. The fifth factor represented Autonomy and refers to independence in work. The sixth factor represented Social support and refers to the relationship with friends and colleagues. Items on the seventh factor related to Job significance, referring to the significance of the work. The eighth factor represented Emotional demands and refers to emotionally demanding situations at work.

Table 4 illustrates the means, standard deviations, internal consistencies and correlations between variables of the JD-RQ.

As can be seen from Table 4, all scales show acceptable reliabilities varying from 0.70 (Autonomy) to 0.86 (Instrumental Support). All these scales of reliabilities were higher than the guideline of $\alpha>0.70$ (Nunnally \& Bernstein, 1994), except for job significance $(\alpha=0.66)$. All items of all the scales were retained after the reliability analyses.

Almost all the scales show statistically significant correlations except for the correlation between Job significance and Pace and amount of work, and Instrumental support and Emotional demands. Inspection of Table 4 indicates a practically significant positive correlation between Pace and amount of work and Emotional demands (medium effect). There is a practically significant positive correlation between Growth opportunities and Instrumental support (medium effect), Congregational support (large effect), Social support (medium effect) and Job significance (medium effect). Furthermore, there is a practically significant negative correlation between Growth opportunities and Autonomy (reversed scale) and Emotional demands (both medium effect).

Regarding Support, Table 4 demonstrates that there is a practically significant positive correlation between Instrumental support and both Congregational support and Social support (both medium effect), whereas there is a practically significant negative correlation between the former and Emotional demands (large effect). A practically significant positive correlation exists between Congregational support and Social support (large effect) and Job significance (medium effect), although there is a practically significant negative correlation between Congregational support and Autonomy (reversed scale) (large effect) and Emotional demands (medium effect). A practically significant negative correlation exists between Social support and Emotional demands (medium effect). It is evident from Table 4 that a practically significant negative correlation exists between Autonomy (reversed scale) and Social support (medium effect) whereas a practically significant positive correlation exists between the former and Emotional demands (medium effect).

A simple principal component analysis was then carried out with the eight factors of the JD-RQ. An analysis of the eigen values (> $1.00)$ indicated that two factors could be extracted. These factors explained $60 \%$ of the total variance. The results of the principal factor analysis with loadings of variables on factors are shown in Table 5. Labels are suggested for each factor in a footnote.

Table 5 shows that the principal component analysis with a direct oblimin rotation on the eight factors of the JD-RQ resulted in two second-order factors. Items loading on the first factor related to Job resources and included Growth opportunities, Instrumental support, Congregational support, Autonomy, Social support, and Job significance. The second factor represented Job demands and referred to Pace and amount of work and Emotional demands.

\section{DISCUSSION}

The aim of this study was to investigate the job demands and Job resources ministers experience in the ministry. Ministers participating in the study experienced growth opportunities, instrumental support, congregational support, autonomy, social support and job significance as job resources whereas they considered pace and amount of work and emotional demands as job demands. Furthermore, it was found that when ministers experienced an increase in the pace and amount of their work, they also experienced an increase in emotional demands. This

TABLE 4

Means, standard deviations, alpha coefficients and correlation coefficients between the variables

\begin{tabular}{|c|c|c|c|c|c|c|c|c|c|c|c|c|}
\hline \multirow[b]{2}{*}{ Item } & \multicolumn{2}{|c|}{ TOTAL } & \multicolumn{2}{|c|}{ ITEM } & \multirow[b]{2}{*}{$\alpha$} & \multirow[b]{2}{*}{1} & \multirow[b]{2}{*}{2} & \multirow[b]{2}{*}{3} & \multirow[b]{2}{*}{4} & \multirow[b]{2}{*}{5} & \multirow[b]{2}{*}{6} & \multirow[b]{2}{*}{7} \\
\hline & Mean & $S D$ & Mean & $\overline{S D}$ & & & & & & & & \\
\hline 1. Pace and amount of work & 25.37 & 5.53 & 3.62 & 0.77 & 0.84 & - & - & - & - & - & - & - \\
\hline 2. Growth opportunity & 36.05 & 5.56 & 4.01 & 0.62 & 0.84 & $-0.27^{*}$ & - & - & - & - & - & - \\
\hline 3. Instrumental support & 22.35 & 6.85 & 3.19 & 0.98 & 0.86 & -0.24 & $0.42^{*+}$ & - & - & - & - & - \\
\hline 4. Congregational support & 29.35 & 5.39 & 3.67 & 0.67 & 0.82 & $-0.25^{*}$ & $0.61^{*++}$ & $0.47^{*+}$ & - & - & - & - \\
\hline 5. Autonomy & 10.45 & 3.78 & 1.74 & 0.63 & 0.70 & $0.24^{*}$ & $-0.43^{*+}$ & $-0.28^{*}$ & $-0.50^{*++}$ & - & - & - \\
\hline 6. Social support & 16.10 & 3.55 & 4.02 & 0.89 & 0.84 & $-0.19^{*}$ & $0.49^{*+}$ & $0.43^{*+}$ & $0.51^{*++}$ & $-0.31^{*+}$ & - & - \\
\hline 7. Job significance & 18.30 & 1.88 & 4.57 & 0.47 & 0.66 & 0.08 & $0.40^{*+}$ & 0.08 & $0.31^{*+}$ & $-0.21^{*}$ & $0.18^{\star}$ & - \\
\hline 8. Emotional demands & 15.37 & 4.22 & 3.08 & 0.84 & 0.79 & $0.49^{*+}$ & $-0.37^{*+}$ & $-0.56^{*++}$ & $-0.48^{*+}$ & $0.39^{*+}$ & $-0.33^{*+}$ & 0.04 \\
\hline
\end{tabular}

Statistically significant: $p \leq 0.05$

Practically significant correlation (medium effect): $0.30 \leq r \leq 0.49$

${ }^{++}$Practically significant correlation (large effect): $r \geq 0.50$ 
TABLE 5

Principal factor analysis with a direct oblimin rotation on the factors of the JD-RQ

\begin{tabular}{lcc}
\hline ITEM & ${ }^{\mathrm{a}}$ & $\mathbf{2}$ \\
\hline Pace and amount of work & -0.20 & $\mathbf{0 . 6 8}$ \\
Growth opportunities & $\mathbf{0 . 8 4}$ & 0.08 \\
Instrumental support & $\mathbf{0 . 5 5}$ & -0.37 \\
Congregational support & $\mathbf{0 . 8 3}$ & -0.04 \\
Autonomy & $\mathbf{- 0 . 6 3}$ & 0.08 \\
Social support & $\mathbf{0 . 6 8}$ & -0.04 \\
Job significance & $\mathbf{0 . 6 3}$ & 0.68 \\
Emotional demands & -0.45 & $\mathbf{0 . 6 6}$ \\
\hline
\end{tabular}

a Factor labels: 1 - Job Resources, 2 - Job Demands

resulted in less autonomy, growth opportunities and less instrumental, congregational and social support.

Ministers are in an occupation that is considered unique due to their unique work-related and client-related stressors (Redelinghuys \& Rothmann, 2005). Evers and Tomic (2003) found that ministers experience significantly more stress than professionals in other fields. The reason for this can be due to ministers' ambivalent role and their different responsibilities. However, there are only a few studies that have examined the unique stressors of a minister's work. Therefore, the aim of this study was to explore the job demands and job resources that ministers experience in the ministry. The results of this study indicated that ministers experienced eight different job characteristics. These eight job characteristics were classified into two categories: job demands and job resources. Identified job demands included pace and amount of work and emotional demands, while the job resources included growth opportunity, instrumental support, congregational support, autonomy, social support and job significance.

Pace and amount of work referred to the amount of work that needs to be done by a minister in his occupation, the time pressure a minister experiences in doing his work and the demanding situations within his occupation. Overload is a commonly found stressor in the ministry (Kriel et al., 2005). According to Grobbelaar (2007), ministers experience overload because they have a large amount of work to do apart from their primary role of preaching. Blanton and Morris (1999) also indicated that time is a frequent resource demanded from ministers in the ministry.

Growth opportunities referred to the variety in a minister's work the opportunities a minister has to learn and develop, and the feeling of accomplishment in the ministry. Another component that formed part of this factor was the time a minister has for his own spiritual growth. Interestingly, Grobbelaar (2007) indicated that because of the amount of work that ministers experience, they also do not have enough time for their own spiritual growth. The qualitative results in this study showed ministers did indeed encounter some opportunities to grow spiritually and also to learn and develop their own abilities.

The third factor, instrumental support, referred to the financial, administrative and co-worker support a minister enjoys in the ministry. Other studies found that ministers perceive financial compensation as a chronic stressor (Morris \& Blanton, 1994). This was also found by Grobbelaar (2007) who indicated that ministers saw their financial compensation as a big problem: ministers felt that their compensation was not enough for the work that they did in the ministry. This study indicated that the financial compensation ministers received could be seen together with administrative and co-worker support as a support mechanism. Mostly, ministers indicated that they only received this support some of the time. Although ministers considered this a support mechanism, the qualitative results suggested that ministers do not believe they receive sufficient instrumental support.

Congregational support referred to the support a minister receives from the congregation and Church council. Ministers indicated that they received support from the congregation and Church council but not to a great extent. Support is probably the most well known situational variable that has been proposed as a potential buffer against job strain (Bakker \& Demerouti, 2006). Therefore, ministers need to be supported by the congregation and Church council in order to fulfil their roles as ministers optimally.

Autonomy referred to the independence in the work of a minister. Kriel et al. (2005) stated that ministers are in a way free to do what they think is important to do. However, ministers are still bound by the Church Order to perform their primary roles of preaching, teaching and pastoral care (Burger \& Wepener, 2004).

The sixth factor, social support, referred to the relationship a minister has with friends and colleagues. Social support emerges from the availability of friendships, social activities and relationships in one's social network (Blanton \& Morris, 1999). Based on the research of Blanton and Morris (1999), social support can be seen as an important resource for ministers.

Job significance referred to whether or not a minister's work is important to him and whether or not he has an effect on other people. Ministers perceive their work as a calling and as a result the work that a minister does is focused on enriching people's lives with the Word of God (Smit, 2004). Consequently, ministers have a strong effect on other people's lives and see their work as important for others and for themselves.

The last factor, namely emotional demands, referred to the emotional situations ministers face in their occupation. Many studies have demonstrated that people with personal problems seek the help of ministers first or early in their stressful situation (Darling, Hill \& McWey, 2004). Ministers frequently provide counselling to parishioners in the areas of marriage and family conflict, morality, career concerns, suicide, panic disorders and emotionally debilitating issues of anger, depression and fear or anxiety (Blanton \& Morris, 1999). Furthermore, parishioners report that they are seven times more likely to seek the assistance of the minister for their marriage and family problems than the assistance of a non-religious mental health specialist (Darling et al., 2004). This also seemed to be the case in this study: ministers reported that they experienced a certain number of emotional demands in their work.

It was found that Pace and amount of work correlated positively with Emotional demands: when ministers experienced more emotional demands (e.g. pastoral counselling), they were also likely to experience more work with less time to complete it. Blanton and Morris (1999) are of the opinion that work-related stressors like overload have a greater impact on ministers' emotional health than economical or demographical factors. There is a strong increase in mental and emotional workloads on professionals. Today more individuals than ever before are confronted with the emotional demands that are associated with working for other people daily. People describe the cause of their personal worries and difficulties more psychologically than people did some decades ago (Tomic et al., 2004).

Interestingly, emotional demands were also found to correlate negatively with growth opportunities, indicating that when ministers had more emotional demands they experienced less Growth opportunities. Therefore, when ministers' pace and amount of work increased, their emotional demands (the emotional situations a minister is faced with in his occupation) also increased and this resulted in their experiencing less feelings of accomplishment, less variety and opportunities to learn and develop. This can be problematic because it is exactly when the emotional demands of a minister's work increases that he must rely on his own spiritual growth and feelings of accomplishment. 
This was also the case with all three factors of support (namely instrumental, congregational and social support). The more emotional demands ministers were subjected to, the less instrumental support and support from family, friends, congregation, and Church council they seemed to experience. Previous research found that persons in care-giving roles who had functional and structural support, such as time spent working, sleeping and visiting with family and friends seemed to be less at risk from the stressful effects of care-giving (Darling et al., 2004). This suggests that some job resources may directly prevent energy-depletion (Bakker et al., 2003a). Indeed, research has found that social support protects employees from the pathological consequences of stressful experiences (Bakker \& Demerouti, 2006). Social support therefore can buffer the impact of job demands or emotional demands (Bakker \& Demerouti, 2006). In this study it became clear that ministers should receive more support in cases of emotionally demanding situations.

Emotional demands were found to correlate positively with the reversed scale of autonomy, indicating that when ministers experienced more emotional demands they experienced less autonomy. There is general support for the proposition that jobs which enhance employees' autonomy or control over their work promote their well-being and job satisfaction (Kay, 2000). This was also the case with the ministers in the study; the more autonomy, the less demands experienced. Hence, if a minister is given the opportunity to decide his own way of working, he will also take on fewer responsibilities, decreasing his workload and emotional demands. This line of reasoning is also seen in Warr's Vitamin model where autonomy is considered to be an AD vitamin. Warr argues that autonomy is good for a person's health until it reaches a plateau (health remains constant) but if autonomy further increases in the work it will become harmful and impair mental health (De Jonge \& Schaufeli, 1998).

Additionally, autonomy (reversed scale) correlated negatively with social support and congregational support, therefore where ministers experienced less autonomy they also experienced less support from friends, family and the congregation. This was also the case with growth opportunity: the less autonomy ministers experienced the less growth opportunities they felt they had. When a minister's tasks become increasingly heavier and these tasks cannot be carried out adequately without the help or support from others, then, cooperation with colleagues and professional support become increasingly more important to keep the minister going.

Growth opportunities were found to correlate positively with all three factors of experienced support. Therefore, the more support experienced, the more ministers felt that there were opportunities in which they could grow. Rothmann et al. (2006) found in their study regarding job demands and job resources of South Africans that growth opportunities do indeed correlate with support. When ministers experience more growth opportunities, they also experience more support and job significance.

Furthermore, congregational support seemed to be related to social support. Accordingly, the more support ministers received from their congregation, the more support they appeared to receive from friends. This can be due to the fact that some of their friends were also members of their congregations. Therefore, when a minister received support from his friends he also received support directly from the congregation. In previous research it was found that the coping method least used was the acquisition of social support (Darling et al., 2004). Congregational support was also positively related to Job significance, indicating that when a minister received more support from his congregation he experienced more Job significance. This resulted in his feeling that his efforts were significant and valued.

Overall, these findings confirm some but not other results of previous studies. Ministers, like other professionals, are subjected to occupation-related stressors that can place heavy strains and demands on their job resources and which can inhibit their growth and supportive relationships. Furthermore, the study indicated that when ministers lacked job resources, they were unable to reduce the potentially negative influence of high job demands (e.g. emotional demands). Job resources therefore, are not only important to deal with job demands but are also important in their own right (Bakker \& Demerouti, 2006).

\section{Limitations}

Although the research showed promising results, it is also important to note some limitations of this study. The first limitation relates to the sample size. Because there are only 232 ministers in the Reformed Church of South Africa, the study population consisted of only 115 participants. Therefore, the results of this study cannot be generalised to all ministers of the Reformed Church. Given the small sample size, the results of the factor analyses should be interpreted with caution. In general, exploratory factor analysis is a large sample procedure with a requirement of at least five respondents for each item. This means that a sample size of 320 (the product of 64 items and 5 respondents per item) would have been more appropriate for this study. However, according to Costello and Osborne (2005), strict rules regarding sample size for exploratory factor analysis are disappearing. The adequate sample size is partly determined by the nature of the data. If the data is strong (i.e. communalities are high, cross loadings are low, and several variables load strongly on each factor) as was the case in this study, a smaller sample size is acceptable. The second limitation was that the study was only done on one denomination and therefore conclusions about this study can only be drawn within the confines of the Reformed Church and cannot be generalised to apply to all ministers in South Africa.

\section{Conclusion}

The results of this study have important implications for ministers and for future research. It is recommended that the occupation of a minister be examined more closely. There were a few participants who commented on several items of the questionnaire, especially items regarding the financial support of ministers. The reason for this can be that ministers perceive their work as a calling and are not in the ministry because they are paid to do the work of a minister. It is therefore recommended that these items be rephrased in follow-up studies. Furthermore, some of the ministers commented that they felt they needed to explain why they were answering a question in a certain way. They also felt that some of the scales of the question were not applicable to the question. It is therefore recommended that future studies ask more open-ended questions in order for ministers to explain more of their answers.

Next, it is recommended that different congregations are looked at more closely because they may demand different things from a minister. Kriel et al. (2005) found in their study that congregation size, second ministerships and years in the ministry had a strong effect on the joy ministers experienced in their life. The last recommendation is to include other denominations in future research. This will enable a closer comparison between denominations and make it possible to draw conclusions regarding ministers in general.

\section{REFERENCES}

Bakker, A.B., \& Demerouti, E. (2006). The job demands-resources model: State of the art. Journal of Managerial Psychology, 22, 309-328.

Bakker, A.B., Demerouti, E., \& Schaufeli, W.B. (2003a). Dual processes at work in a call centre: An application of the job demands-resources model. European Journal of Work and Organizational Psychology, 12, 393-417.

Bakker, A.B., Demerouti, E., Taris, T.W., Schaufeli, W.B., \& Schreurs, P.J.G. (2003). A multigroup analysis of the job demands-resources model in four home care organizations. International Journal of Stress Management, 10, 16-38. 
Blanton, P.W., \& Morris, M.L. (1999). Work-related predictors of physical symptomatology and emotional well-being among clergy and spouses. Review of Religious Research, 4, 331-348.

Burger, C.W. (2004). Die predikantsamp. Deel 4: Predikantwees in die Gereformeerde tradisie in die 21ste eeu - nuwe uitdagings en nuwe tendense. Nederduitse Gereformeerde Teologiese Tydskrif, 45(3/4), 529-537.

Burger, C.W., \& Wepener, C.J. (2004). Die predikantsamp. Deel 1: Onduidelikheid oor die kerkinhoud van die predikantsamp. Nederduitse Gereformeerde Teologiese Tydskrif, 45(1/2), 6-14.

Burns, N., \& Grove, S.K. (1993). The practice of nursing research, conduct, critique, and utilization (2nd edn.). Philadelphia: W.B. Saunders.

Clark, L.A., \& Watson, D. (1995). Constructing validity: Basic issues in objective scale development. Psychological Assessment, 7, 309-319.

Costello, A.B., \& Osborne, J.W. (2005). Best practices in exploratory factor analysis: Four recommendations for getting the most from your analysis. Practical Assessment, Research, and Evaluation, 10(7), 1-9.

Coetzer, W. (2004). "Medelyemoegheid" - die hantering van sekondere traumatiese stres. Koers, 69(2), 199-219.

Darling, C.A., Hill, E.W., \& McWey, L.M. (2004). Understanding stress and quality of life for clergy and clergy spouses. Stress and Health, 20, 261-277.

De Jonge, J., Dormann, C., Janssen, P.P.M., Dollard, M.F. Landeweerd, J.A., \& Nijhuis, F.J.N. (2001). Testing reciprocal relationships between job characteristics and psychological well-being: A cross-lagged structural equation model Journal of Occupational and Organizational Psychology, 74, 29-46.

De Jonge, J., \& Schaufeli, W.B. (1998). Job characteristics and employee well-being: A test of Warr's Vitamin model in health care workers using structural equation modeling. Journal of Organizational Behavior, 19, 387-407.

Demerouti, E., Bakker, A.B., Nachreiner, F., \& Schaufeli, W.B. (2001). The job demands-resources model of burnout. Journal of Applied Psychology, 86, 499-512.

Evers, W., \& Tomic, W. (2003). Burnout among Dutch Reformed pastors. Journal of Psychology and Theology, 31, 329-338.

Giorgi, A. (1985). Sketch of a psychological phenomenological method. In A. Giorgi (Ed.), Phenomenology and psychological research. Pittsburgh: Duquesne University Press.

GKSA. Kerkorde van die Gereformeerde Kerke in Suid-Afrika. (1862). Retrieved March 4, 2008, from http://www.gksa.org. $\mathrm{za} /$

Grobbelaar, K.G. (2007). Hulpverlening tot streshantering by predikante van die Gereformeerde Kerke in Suid-Afrika (GKSA): 'n Pastorale studie. Unpublished doctoral thesis, North-West University, Potchefstroom, South Africa.

Hackman, J.R., \& Oldham, G.R. (1976). Motivation through the design of work: Test of a theory. Organizational Behavior and Human Performance, 16, 250-279.

Hackman, J.R., \& Oldham, G.R. (1980). Work redesign. Reading: Addison Wesley.

Han, J., \& Lee, C. (2004). Ministry demand and stress among Korean American pastors: A brief report. Pastoral Psychology, 52, 473-478.

Janssen, P.P.M., Peeters, M.C.W., De Jong, J., Houkes, I., \& Tummers, G.E.R. (2004). Specific relationships between job demands, job resources and psychological outcomes and the mediating role of negative work-home interference. Journal of Vocational Behavior, 65, 411-429.

Kay, W.K. (2000). Job satisfaction of British Pentecostal ministers. Asian Journal of Pentecostal Studies, 3(1), 83-97.

Kerlinger, F.N. (1986). Foundations of behavioral research (3rd edn.) Fort Worth: Harcourt Brace College.

Kompier, M. (2003). Job design and well-being. In M.J. Schabracq, J.A.M. Winnubst \& C.L. Cooper (Eds.), The handbook of work $\mathcal{E}$ health psychology (pp. 429-454). John Wiley \& Sons.

Krause, N., Ellison, C.G., \& Wulff, K.M. (1998). Church-based emotional support, negative interaction, and psychological well-being: Findings from a national sample of Presbyterians. Journal of the Scientific Study of Religion, 37, 725-741.

Krefting, L. (1991). Rigor in qualitative research: The assessment of trustworthiness. The American Journal of Occupational Therapy, 45, 214-222.

Kriel, J.S., Wilders, C.J., Strydom, G.L., \& Breytenbach, H.S (2005). Die interaksie van fisieke aktiwiteit met die verband tussen lewensgeluk en diensjare, gemeentegrootte, medeleraarskappe en gemeentetipe by NG predikante in Suid-Afrika. Nederduitse Gereformeerde Teologiese Tydskrif, 46(1/2), 165-179.

Le Blanc, P.M., Bakker, A.B., Peeters, M.C.W., Van Heesch, N.C.A., \& Schaufeli, W.B. (2001). Emotional job demands and burnout among oncology care providers. Anxiety, Stress and Coping, 14, 243-263.

Lee, C. (1999). Specifying intrusive demands and their outcomes in congregational ministry: A report on the ministry demands inventory. Journal for the Scientific Study of Religion, 39, 477-489.

Morris, M.L., \& Blanton, P.W. (1994). The influence of workrelated stressors on clergy husbands and their wives. Family Relations, 43, 189-195.

Nunnally, J.C., \& Bernstein, I.H. (1994). Psychometric theory (3rd edn.). New York: McGraw-Hill.

Psalmboek. (2003). Die berymde en omgedigte psalms en ander skrifberymings in gebruik by die Gereformeerde kerke in SuidAfrika. Paarl: NG Kerk Uitgewers.

Redelinghuys, F.J., \& Rothmann, S. (2005). Koherensiesin, coping, uitbranding en begeestering van predikante. Tydskrif vir Geesteswetenskappe, 45, 466-477.

Rodrìguez, I., Bravo, M.J., \& Peiró, J.M. (2001). The demandscontrol-support model, locus of control and job satisfaction: A longitudinal study. Work and Stress, 15, 97-114.

Rothmann, S., Mostert, K., \& Strydom, M. (2006). A psychometric evaluation of the job demands-resources scale in South Africa. South African Journal of Industrial Psychology, 32, 7686.

Roux, G.B. (1992). Stressore in die bediening en die uitwerking daarvan op spesifieke persoonlikheidsaspekte van die predikant. Nederduitse Gereformeerde Teologiese Tydskrif, 33(1/2), 225-231.

Schaufeli, W.B., \& Bakker, A.B. (2004). Job demands, job resources, and their relationship with burnout and engagement: A multi-sample study. Journal of Organizational Behavior, 25, 293-315.

Scholtz, D.A. (1996). Die voorspelling van beroepsukses onder 'n groep diensdoenende predikante. Unpublished doctoral thesis, Potchefstroom University for Christian Higher Education, Potchefstroom, South Africa.

Smit, J. (2004). Die predikant: 'n Werknemer van die kerkraad? Nederduitse Gereformeerde Teologiese Tydskrif, 45(1/2), 88-98.

SPSS Inc. (2003). SPSS 12.0 for Windows. Chicago: SPSS.

Tomic, W., Tomic, D.M., \& Evers, W.J.G. (2004). A question of burnout among Reformed Church ministers in the Netherlands. Mental Health, Religion E Culture, 7, 225-247.

Van den Berg, J-A. (2004). 'n Hoofstuk in die (outo)biografie van die predikant (pastor?). Acta Theologica Supplementum, 6, 183-206.

Van Derdoef, M., \& Maes, S. (1999). The job demand-control(support) model and psychological well-being: A review of 20 years of empirical research. Work and Stress, 13, 87-114.

Van der Merwe, W.L. (1996). Philosophy and the multi-cultura context of (post)apartheid South Africa. Ethical Perspectives, $3 / 2,76-90$

Warr, P. (1994). A conceptual framework for the study of work and mental health. Work and Stress, 8, 84-97.

Wepener, C.J. (2004). Die predikantsamp. Deel 3: Die take van die predikant in die Gereformeerde tradisie -.histories en ekumenies beskou. Nederduitse Gereformeerde Teologiese Tydskrif, 45(1/2), 152-165.

Woods, N.F., \& Catanzaro, M. (1988). Nursing research: Theory and practice. St Louis: Mosby. 